\title{
Improvement of Organizational and Judicial Frameworks of State Bodies with Appeals of Legal and Physical Entities
}

\author{
Yusupov Sardorbek, Dildora Abdusattarova
}

\begin{abstract}
The aim of the research is to develop proposals and recommendations aimed at improving the organizational and legal framework for the work of state bodies with appeals from individuals and legal entities.

The object of the research is considered to be the system of social relations connected with the organizational and legal bases of the work of state bodies with appeals of individuals and legal entities in the Republic of Uzbekistan.

The scientific novelty of the research is as follows:

in order to clarify the scope of the Law of the Republic of Uzbekistan «On Appeals of Individuals and Legal Entities», as well as when dealing with state authorities, one person submitted several appeals of the same content several times, accepting appeals through video communication and legal assessment, clarifying copies of the appeals of exactly the same content. Such legal concepts as «repeated appeal», «duplicate appeal», «video conferencing»;

justified the need for the government body reviewing the appeal, the decision to terminate the consideration of the appeal, if new reasons are not given new reasons or newly discovered circumstances, if the previous materials of the appeal contain comprehensive verification materials and the appellant answers in the prescribed manner;

The necessity of the announcement on official websites of the relevant state bodies of references (comments), compiled on the basis of the results of the association and analysis of appeals;

when clarifying the scope of the Law «On Internal Affairs Agencies», as well as when dealing with appeals of individuals and legal entities, the necessity of a report by an employee of the internal affairs bodies of their positions, titles, surnames, first names and patronymic when they are addressed to a citizen, the obligation to listen carefully.
\end{abstract}

Keywords: law, appeals, organizational and legal framework, repeated appeal, duplicate appeal.

\section{INTRODUCTION}

In the world, the circulation of persons, the problem of legal regulation of relations between citizens and public institutions is becoming increasingly global and relevant. In particular, United Nations General Assembly Resolution 53/144 notes as one of the most important political rights the exercise of the right to submit, individually or in association with others, to government bodies and institutions, as well as to organizations involved in the conduct of public affairs, criticism and suggestions for improving their activities. In this regard, it is a dictate of the time to consider the appeals of individuals in all states, the authorized bodies, to take impartial and fair decisions, to take the necessary measures

Revised Manuscript Received on October 15, 2019.

Yusupov Sardorbek, Tashkent state university of law, sardor Uzbekistan(E-mail: s.yusupov020@mail.ru)

Dildora Abdusattarova, Associate professor at Finance and Taxes department, Tashkent State University of Economics, Uzbekistan(E-mail: dildora0386@gmail.com) to solve the problems of the individual, as well as to carry out legal reforms aimed at protecting the political rights of the individual by the international community.

In the world, on the basis of the definition of specific areas of legal regulation of the right of the individual to appeal and its full implementation, special attention is paid to scientific research on the improvement of this sector and the implementation of the constitutional rights of citizens. In this connection, it is important to study the legal regulation of issues related to ensuring the right of the individual (persons) to petition, increasing the share of information technologies in "smart legal regulation" models, and improving new effective mechanisms for the consideration of complaints. In addition, to date, the study of the problems of improving the organizational and legal framework for the work of State bodies dealing with applications from individuals and legal entities at the national and international levels has become a separate topic of study.

At a new qualitative stage of the social and economic progress of our country, comprehensive protection of the right of individuals and legal entities to appeal, the development of authoritative forms of effective public control over the activities of State bodies, timely consideration of appeals has been raised to the level of State policy. The idea that "It is not the people who serve the state bodies, but the state bodies that should serve the people". The National Commission for Social Development has been identified as one of the priority areas for the development of society.

This dissertation study to a certain extent serves to ensure the implementation of the Laws "On Applications of Natural and Legal Persons" № 445 of September 11, 2017, "On the Commissioner for Human Rights of the Oliy Majlis (Ombudsman)" № 441 of August 29, 2017, Decrees of the President of the Republic of Uzbekistan "On measures to radically improve the system of work with appeals of individuals and legal entities" No. UP 4904 of December 28, 2016, "Concept of administrative reform in the Republic of Uzbekistan" No. UP 5185 of September 8, 2017, "On the Strategy of action for further development of the Republic of Uzbekistan" No. UP 4947 of February 7, 2017 and approved by the Cabinet of Ministers Decree № 341 of the Model Regulations "On the order of work with appeals of individuals and legal entities in public authorities, public institutions and organizations with state participation" of May 7, 2018, as well as other legal acts on the subject. 


\section{LITERATURE REVIEW \& RESULTS}

A number of questions relating to the right to appeal in Uzbekistan's legal studies have been analysed, primarily in constitutional law, and the international legal framework for the exercise of the right to appeal has been studied by specialists in international law.

Some questions of organizational and legal basis for the work of state bodies in dealing with applications from individuals and legal entities are to a certain extent considered in the scientific works of scientists from our country, H.R. Alimov, B.E. Kosimov, Z.M. Islamov and N.T. Ismoilov,

H.T. Adylkaryeva, A.H. Saidova, O.T. Khusanova, I.A. Khamedov, etc.

In foreign countries some questions of organizational and legal basis of work of state bodies with appeals of individuals and legal entities have also been studied, and theoretical aspects related to these questions have been studied by Y.N. Alistratov, A.A. Dvorak,

T.A. Nikolaeva, A.V. Novikov, M.N. Mironov, M.V. Skryabinoy,

S.A. Shirobokov, N.Y. Khamaneva, M.F. Kharadzhiev.

However, the abovementioned works of the scientists do not disclose in detail the relations on the appeal of citizens, especially legal entities, the legal mechanism of work with them, the essence and content, problems associated with the legal framework and the order of consideration of appeals of individuals and legal entities. For this reason, a comprehensive study of this issue is considered relevant.

The scientific novelty of the study is as follows:

In order to clarify the scope of application of the Law of the Republic of Uzbekistan "On applications of individuals and legal entities", as well as in the case of state bodies with applications, the submission of one person to several times the same content, the acceptance of applications through video communication and legal assessment, clarification of copies of applications of the same content is supplemented by such legal concepts as "repeated application", "copy of the application", "video conferencing";

the need for the state body considering the appeals to take a decision to discontinue consideration of the appeal has been justified, unless the repeated appeals contain new reasons or newly discovered circumstances, if the previous materials of the appeal contain comprehensive materials of the inspection and the applicant has been answered in accordance with the established procedure;

The necessity of announcing on the official websites of the relevant state bodies the references (comments) drawn up based on the results of the merger and the analysis of appeals has been justified;

In clarifying the scope of application of the Internal Affairs Bodies Act and in dealing with communications from individuals and legal entities, the need for a report by an internal affairs officer on his or her position, title, surname, first name and patronymic when addressing him or her has been justified, as has the obligation to listen carefully to him or her.

The practical results of the study are as follows:

Proposals have been drawn up to simplify the process of handling citizens' communications, as provided for in the Administrative Liability Code, the Code of Civil Procedure and the Communications from Natural and Legal Persons Act;

Proposals have been developed to amend and supplement the Model Regulation "On the Procedure for Handling Applications from Individuals and Legal Entities in State Bodies and State Institutions" approved by the Cabinet of Ministers;

Proposals have been made to further strengthen the reliable protection of applicants in relations between individuals and legal entities with regard to applications to State bodies and officials;

Proposals have been developed to further improve the system for handling complaints and to create the most optimal mechanisms for doing so.

Reliability of the results of the study. The results of the research are based on national legislative norms, experience of developed countries, law-enforcement practice, interviews and forms of expert assessment, results of social survey, and results of analysis of statistical data, consolidated and formalized by the relevant documents. Conclusions, proposals and recommendations have been tested and published in leading national and foreign publications. The results have been approved by the competent authorities and implemented in practice.

The results of the study on the improvement of the organizational and legal framework for the work of State bodies in dealing with applications from individuals and legal entities were used in the following areas:

Proposals to clarify the scope of application of the Internal Affairs Bodies Act and to establish cooperation in the work of internal affairs bodies with applications from individuals and legal entities were used in the drafting of article 8 , paragraph 8 , and article 16 , paragraph 4 , paragraph 1 , of the Internal Affairs Bodies Act (reference No. 06/206/170 of 26 January 2017 from the Defence and Security Committee of the Legislative Chamber of the Oliy Majlis). Implementation of these proposals will serve to clarify the scope of application of the law, the implementation of systematic cooperation in the field of internal affairs bodies with appeals of individuals and legal entities;

Proposals on the application of norms to ensure the right of citizens to appeal were used in the development of paragraph 3 of Part 4 of Article 28 of the Law of the Republic of Uzbekistan "On Internal Affairs Bodies" (reference number $06 / 2-06 / 170$ of the Committee on Defense and Security of the Legislative Chamber of the Oliy Majlis of the Republic of Uzbekistan on 26 January 2017). The implementation of these proposals will serve to ensure compliance with international standards for the operational work of the internal affairs bodies in carrying out their official tasks;

proposals to clarify the scope of application of the Law of the Republic of Uzbekistan "On Applications of Individuals and Legal Entities", to identify and eliminate the causes of violations by state bodies considering applications of the rights, freedoms and legitimate interests of individuals, as well as the interests of society and the state, were used in

Published By:

Blue Eyes Intelligence Engineering 
making changes and additions to parts 2-3 of article 1, part 2-3 of article 3 , part 1 of article 5 , part $1-2-3$ of article 21 , part 2-3 of article 28 , part 2-3 of article 29 , part 2-3-4 of article 30 , part $1-2-3$ of article 35 , adopted in the new version of the Law of the Republic of Uzbekistan. These proposals will serve to detail the order and timing of processes related to the improvement of the organizational and legal framework for the work of state bodies with appeals from individuals and legal entities.

\section{CONCLUSION}

As a result of the conducted researches on the theme of the dissertation "Improvement of the organizational and legal basis of the work of state bodies with the appeals of individuals and legal entities" the following theoretically and scientifically - practical significance, conclusions and proposals were formulated.

The historical mechanism for the exercise of the right of individuals and legal entities to appeal in Uzbekistan is specific to the democratic nature of State power. This mechanism is linked to the popular and democratic nature of State power. The appeal has gathered extensive experience in safeguarding human rights and interests, establishing constitutional and legal institutions and mechanisms and setting up their activities.

2. According to international instruments, work with citizens' appeals is one of the areas (forms) in which State bodies carry out their functions and powers. The mechanism of international legal regulation in the field of human rights, having a complementary (additional) nature, does not push aside the national legal mechanisms.

Appeals from individuals and legal entities, as an institution of complex content, are expressed as a specific model for the work of State bodies with applications, complaints and proposals within the framework of the law, as well as a form of public oversight of the activities of State bodies in the form of a specific mechanism for their resolution. The peculiarity of the institution of appeals is expressed in its complex nature and in the organizational and legal mechanism for the implementation and enforcement of this right.

Appeals from individuals and legal entities are not only one of the most important forms of protection and effective safeguarding of their rights and interests, but also a means at present. This means of addressing can have a tangible impact on the activities of public authorities, the content of their decisions and actions. Generalization and analysis of the problems and shortcomings referred to in the applications is a means of determining the social and political activity of citizens, identifying the degree of public trust in State institutions, identifying and eliminating shortcomings in the organization of the work of State bodies, and influencing the decisions and activities of State bodies. Analysis of the problems raised in the appeals and their generalization is an indicator (indicator) of the social activity of civil society institutions. They perform the task of expressing their trust in state institutions and identifying shortcomings in the activities of public authorities.

5. Mechanism of work with appeals of individuals and legal entities submitted to state bodies is a system of the order of acceptance of appeals by state bodies regulated by the norms of legislation, the way and means of their consideration. These elements include: the subjects of these relations, the legal norms governing the procedure for consideration, the legal obligations of State bodies, and a set of guarantees for the rights of applicants.

6. Based on the analysis of the legal nature of the right to appeal, the following features and characteristics can be identified: a) the implementation of this right in the form of a constitutional right to appeal; b) it is an expression of the official will of the mass political content of individuals and legal entities, the purpose of which is to influence the decision taken by the state body, its control; c) the obligation to consider appeals by state bodies and officials.

7. Comprehensive authorization of the exercise of the right to appeal makes it possible to create an effective legal mechanism for the protection of this right. The mechanism for the protection of the right to appeal to State authorities, as a separate set of legal means, is a guarantee applicable to preventing restrictions and violations of this right, prosecuting perpetrators and restoring violated rights.

8. The organizational and legal reserves for improving the effectiveness of the work with applications in State bodies should include: in order to strengthen the guarantees of the exercise of the right of individuals and legal entities to receive information, measures should be taken to ensure transparency and openness in the activities of State bodies; the need to define, in the regulatory and legal form, the obligation to announce the results of the consideration of applications on the official websites of State bodies; and the need to

9. The point of our conclusion is that the expression "social and political (mass) services" is broader than the term "public services" in that services in the first category can be provided by both public authorities and public organizations. Public services are directly provided by public authorities and their officials. Speaking of social services, they can also be provided by public authorities themselves. Or the authority to resolve the issue may be given to authorized non-governmental institutions or organizations (for example, self-government bodies or nongovernmental non-profit organizations). For the use of public services, individuals and legal entities, referring to this or that type of public service, can send an appeal. These appeals act as a peculiar means of attracting individuals and organizations to public administration.

10. The state, guaranteeing protection against violations of the right to appeal, by establishing the relevant mandatory rules in the law, in accordance with the treatment expressed to the authorized state body, and, in case of its guilt, provides for the application of appropriate penalties to it. Responsibility for violation of the legislation on appeals of physical and legal persons, being an important component of the system of the constitutional right to appeal, is considered as an auxiliary means of full realization of this right, and also guarantees observance of the legislation in the field of consideration of these appeals by state bodies. 
As a result of comparatively - legal and system analysis of legislative acts in the sphere of constitutional-legal relations, which make up the object of dissertation research, it is proposed to improve them on the basis of the following measures.

11. A number of organizational reserves (opportunities) to improve the efficiency of work with appeals in government agencies include the following: transparency of information about the activities of government agencies, mandatory announcement of the results of work with appeals on official websites, wide introduction of new information and communication technologies in the process of consideration of appeals.

12. The analysis of foreign experience shows that legislation and practice in the field of consideration of applications from individuals and legal entities serves as a means of ensuring their rights and interests, as well as an effective way of protecting various rights of individuals and organizations. Examples of legislation and the practice of some foreign countries may also be used in Uzbekistan to improve the system of work of State bodies in dealing with applications from individuals and legal entities, as well as the relevant legislation.

13. The article substantiates the expediency of forming and maintaining an electronic information system for all proposals received from individuals and legal entities. This system should be open to all applicants concerning their applications. This information can be used to improve the activities of government agencies and relevant legislation.

14. It is proposed to include the following in the resolution

Standard provision: "If there are cases when it is impossible to determine the information (surname of the applicant, name of the legal entity or address) about the applicant, this request remains unexamined, and a protocol is drawn up by the head of the state body. It is proposed that paragraph 4 of this provision, after the sentence "if by the time of receipt of the repeated appeal the term of consideration has expired", be supplemented with the following text: "if such appeal is received before the end of the term of consideration, then both are considered together, and it is not considered repeated". (These proposals have found their expression in the established order in the approved by the Cabinet of Ministers of the Republic of Uzbekistan № 341 Model Regulations "On the order of work with appeals of individuals and legal entities in government agencies, public institutions and organizations with state participation" dated May 7, 2018).

15. It is proposed to supplement paragraph 21 of the Model Provision, approved by the Government Resolution No. 73 with the following norm: "In case of a negative response to the appeal, it shall be evaluated on all its grounds, based on the example of the relevant legislative acts, and the procedure for its appeal shall be explained". (These proposals were duly expressed in the paragraph 6 paragraph 42 of the Model Regulations "On the order of work with appeals of individuals and legal entities in government agencies, public institutions and organizations with state participation" № 341 of May 7, 2018, approved by the Cabinet of Ministers of the Republic of Uzbekistan).
16. The need has been justified to supplement article 18, paragraph 1 , of the Communications from Individuals and Legal Entities Act with the following provision: "One of the following decisions shall be taken as a result of the consideration of communications - The following decisions are taken: "On the outcome of the consideration of applications by individuals and legal entities, one of the following is adopted: on full or partial satisfaction of the application; on the adoption of a reasoned decision to refuse to consider the application; on the provision of explanations as to the content of the application; and on the consideration of the application on the grounds established by law". It is also proposed that the following provision be added to the article: "If the questions raised in the application have been answered several times in writing to the person concerned the following applications do not contain any new cases or facts, and the State body may, after showing that the next application is unfounded, take a decision. The person submitting the application is informed of this decision.

17. It is proposed that after the phrase "the execution of the decision taken in connection with the application" the following text be added to article 43 of the Administrative Liability Code of the Republic of Uzbekistan: "violation of the procedure for informing citizens of the schedule of personal reception, intentional violation of the schedule of personal reception, sending the application for consideration to the person against whose actions the application is filed as well as leaving without consideration of the application on grounds not provided for in the law".

18. It is proposed that the unlawful acts set out in article 43 of the Administrative Liability Code and article 144, paragraph 1 , of the Criminal Code be classified as follows

Article 144, paragraph 1, of the Criminal Code, as amended: "Illegal refusal to accept and consider applications from individuals and legal entities, violation of the terms of their consideration without a valid reason, failure to reply in writing or electronically, acceptance of an application from individuals and legal entities contrary to the law, failure to ensure the restoration of violated rights of individuals and legal entities, execution of a decision taken in connection with the application or disclosure of information about the private life of individuals or the activities of legal entities $b$

19. Special attention should be paid to cases of termination of consideration of an appeal by an authorized body or person. There should be sufficient and specific grounds for such discontinuances. Examination with on-site visits of appeals on mass or repeated violations of the requirements of the law, rights and freedoms, and then the announcement of the results of the detailed examination through the media is of good effect. In order to improve the work with appeals, taking into account the most positive results collected in law enforcement practice, it is recommended to hold exemplary seminars, to create a base of educational and methodical materials, to create a Center of Professional Development at the national level. 
The Model Regulation No. 73 of the Cabinet of Ministers of the Republic of Uzbekistan approved on 31 March 2015 does not define the concept of "control of treatment" or "treatment under control". According to this, we consider it appropriate to supplement paragraph 4 of this Model Provision with the following definition: "The control of an appeal is considered to be taken under control in accordance with the established procedure of an appeal of a natural or legal person sent to the relevant state body or its official employee with an accompanying letter or resolution of the authorized person, on its implementation within the established time limits is reported to the controllers.

(This proposal has found its expression in the established order in paragraph 27 of the Model Regulations "On the order of work with appeals of individuals and legal entities in government agencies, public institutions and organizations with state participation" № 341 of May 7, 2018, approved by the Cabinet of Ministers of the Republic of Uzbekistan).

The Law "On applications of natural and legal persons" (article 23) and the Model Regulations (paras. 29 and 58) state that the response to electronic communications is sent electronically. In this case, a written reply approved and signed by an official shall be sent to the applicant's electronic document. In practice, the majority of heads of state institutions, except for the response

In order to avoid any differences in the interpretation of practice and experience, it is recommended that paragraph 29 (1) of the Model Regulations be supplemented by the following rule: "The response printed on the letterhead of the public authority shall be sent electronically to the person making the request, and the original shall remain with the public authority. If a citizen submits the received reply letter to other institutions, the printed copy of this electronic reply is equal to the original. (These proposals have found their expression in the established order in paragraph 29, the first paragraph of paragraph 34 of the Model Regulations "On the procedure for handling applications from individuals and legal entities in government agencies, public institutions and organizations with state participation" № 341 of May 7, 2018, approved by the Cabinet of Ministers of the Republic of Uzbekistan).

Proposals and recommendations put forward in the research work were justified from the scientific point of view by the method of comparative legal analysis, they were developed in the appropriate order in the form of draft regulatory and legal acts on making changes and additions to a number of laws and regulations of the Cabinet of Ministers of the Republic of Uzbekistan, explanatory notes and comparative tables. 